\title{
Untying the Dilemma of the Tort of Wrongful Interference with Goods in Nigeria
}

\author{
Hemen Philip Faga1, Rita Okpeahior Ngwoke² \\ ${ }^{1}$ Faculty of Law, Ebonyi State University, Abakaliki, Nigeria \\ ${ }^{2}$ College of Law, Igbinedion University, Okada, Nigeria \\ Email: hemenfaga@gmail.com
}

How to cite this paper: Faga, H. P., \& Ngwoke, R. O. (2019). Untying the Dilemma of the Tort of Wrongful Interference with Goods in Nigeria. Beijing Law Review, 10, 1356-1373.

https://doi.org/10.4236/blr.2019.105073

Received: August 19, 2019

Accepted: December 17, 2019

Published: December 20, 2019

Copyright $\odot 2019$ by author(s) and Scientific Research Publishing Inc. This work is licensed under the Creative Commons Attribution International License (CC BY 4.0).

http://creativecommons.org/licenses/by/4.0/

\begin{abstract}
Many complexities arise in commercial transactions dealing in goods and products, which create liability under the different torts of conversion, detinue and trespass, although many of these circumstances also trigger liability under separate principles of contract or property law. Due to the constant conflicts in the application of these torts in case-law jurisprudence, many countries have consolidated the different principles of apportioning liability for product interference or interference with goods into a statutory tort of "wrongful interference with goods". Nigeria is yet to adopt this approach. However, this paper concludes that the discordant application of the torts of conversion, detinue and trespass to goods in judicial decisions in Nigeria exposes a fundamental drawback that requires legislation to correct through the construction of a single unified tort of wrongful interference with goods.
\end{abstract}

\section{Keywords}

Torts, Wrongful Interference with Goods, Jurisprudence, Chattel, Conversion, Detinue, Trespass

\section{Introduction}

Commercial transactions, especially transactions in goods (chattel) are often fraught with complications and liabilities, which tend to converge around the traditional torts of conversion, detinue and trespass to goods. These torts principally protect individuals' economic and proprietary interest in goods from wrongful interference by others (Brazier \& Murphy, 1999: p. 44). However, the essential principles that determine liability in these torts not only congregate around tortious rules, but embrace principles of both property and contract law. This complexity has led directly to two legal issues, which would be the fulcrum 
of this paper. Firstly, as a result of the complexities, which stem from the interplay of the principles of property, tort and contract, both in determining liability and damages, the condition of the law in this area is in a state of confusion in Nigeria (Fekumo, 2000: p. 120; Samuel, 1982: p. 357; Dias, 1989: p. 1220). Thus, the continued retention of the three torts as separate heads of tortious liability has been seriously called to question, as these torts have already metamorphosed in other jurisdictions into a near single tort of "wrongful interference with goods" (Palmer, 1978: p. 629). The new tort to a large extent streamlines legal principles in the three areas of law, and removes the difficulties associated with the uncertainties endemic in the traditional separation of the three torts. In Nigeria however, the law governing these three torts remains the position under the common law. No legislative attempt has yet been made to develop the law on interference of proprietary interest along the lines adopted in other jurisdictions, or to take the benefit offered by consolidation of the three torts. We shall therefore consider how the Nigerian case law has dealt with overlapping factual situations in the absence of consolidation, and the complexities that arise from them.

Second and most importantly, because these torts on wrongful interference with goods are often situated within the framework of contractual or commercial transactions, factual situations presented in court are as much concerned with disputed title to chattel or goods as with their loss. Therefore, we shall examine Nigerian case laws and especially espouse on how these cases develop principles that tend to congeal the law on this aspect into one single principle of liability for wrongful interference with goods. The paper in sections two, three and four discusses the jurisprudence of the three torts of conversion, detinue and trespass to goods respectively. These sections expound the concept of these torts, their nature and different indicators from a case-law analysis. Section five discusses the judicial confusion of the application of these torts in certain borderline cases that involve simultaneous claims under the different torts. The section also analyzes the need for enactment of a law to unify the torts into a distinct tort of wrongful interference with goods. Section six contains the conclusion.

\section{The Jurisprudence of the Tort of Conversion}

An action for conversion which was originally known as "trover" developed upon a legal fiction. It began as an action for trespass upon the case in which it was alleged that the defendant had found the plaintiff s chattel and had wrongfully converted it to his own use (Brazier \& Murphy, 1999: p. 45). The tort initially encroached on the boundaries of the tort of trespass until it was restricted to the principle that the conversion or wrongful dealing with the goods must amount to a "denial of the owner's title" (Rogers, 1998: p. 584). Thus, conversion under the common law came to be understood as an "intentional dealing with goods which is seriously inconsistent with the possession or right to immediate possession of another person" (Brazier \& Murphy, 1999: p. 46). Under the common law, the tort of conversion may be committed in so many different 
ways, so that any comprehensive definition is probably impossible (Rogers, 1998: p. 588). Thus, conversion may be committed by wrongfully taking possession of goods that belongs to another (Owena Bank v. Nigerian Sweets \& Confectionery Co. 1993:698), by wrongfully dispossessing him of them (Shaik \& Co. Ltd. v. Incar 1976:1530), by wrongfully destroying them (Hollins v. Fowler 1975:757), by wrongfully using them (Ordia v. Piedmont Ltd. 1995:516) or simply by wrongfully refusing to give them up when demanded (Amblestone v. London and Kano Trading Co. Ltd. 1923:130). In all these cases, there is a trace of conduct by the defendant, which amounts to a denial of the plaintiff's right, or the assertion of inconsistent rights.

A definition which is frequently acted upon by Nigerian Courts, and which is apt for our purpose, is that "conversion is an act of deliberate dealing with a chattel in a manner inconsistent with another's right whereby that other is deprived of the use and possession of it" (Ihenacho v. Uzochukwu, 1997:268; Uzor v. Anyika, 2002:1161). To be liable, the defendant need not intend to question or deny the plaintiff's rights, it is enough that his conduct is inconsistent with those rights (Owena Bank v. Nigerian Sweets \& Confectionery Co. 1993:711). The wrong is not merely an interference with the plaintiff's possessory interest in his chattel but also an injury to his right or title in them (Civil Design Construction v. SCOA 2007:300).

\subsection{Persons Entitled to Sue for Conversion}

The general rule is that the person who has the right to sue for conversion of goods is that person who can prove that he had at the time of the conversion, either actual possession or the immediate right to possess the goods (Dias, 1989: p. 1245). Three category of persons are identified as having the right to sue for conversion: 1) a persons who is the owner and who is in possession of the goods; 2) a person who is in possession of the goods even though he is not be the owner; and 3) a person who has the immediate right to possess the goods, but without either ownership or actual possession (Rogers, 1998: p. 597).

Usually, where a person has ownership and possession of the goods as in 1) above, there is no problem at all. The owner of goods who is in possession has an absolute right to sue if they are converted by another person. As regards the situation in 2), if the plaintiff is in undisputed possession of the goods at the time of the action, he would also fulfill the requirement of ownership, because of the presumption of law in section 146 of the Evidence Act 2004. This was the position of the Supreme Court in the case of Commissioner of Police \& Anor v. Oguntayo (1993:259). The requirement in the situation raised in 3) however needs fuller comments; what does "an immediate right to possess" mean? The answer was provided in the Oguntayo's case above. In that case, the main issue for determination was "whether a plaintiff who has brought an action for damages for conversion must, in order to succeed prove an ownership title, or whether it is sufficient if he proves a possessory title". Ogwuegbu J.S.C. held that: "at common law mere de facto possession, as against a stranger is sufficient title 
to support an action for a conversion" (Ibid: 271).

Thus, many other situations have been adjudged by courts of law to constitute "a right to immediate possession", thereby giving the holder of such right the power to sue for conversion such as bailment; lien and pledge; sale; license; and finder of goods (Fekumo, 2000: p. 120; Susu, 1996: p. 42; Kodilinye, 1982: p. 205).

\subsection{Modes of Conversion}

There are many modes of committing the tort of conversion, which involves the deliberate dealing with chattel inconsistent with another's right, depriving him of the use and possession of it. Although, some acts that constitute conversion undeniably conflict with the true owner's rights to the goods, the court reserves the discretion to decide whether any acts sufficiently deprive the true owner's rights as to constitute conversion. The grounds upon which the court exercises such discretion have not attained any clarity, however, some important parametres include the extent and duration of control or dominion exercised over the goods, the intention and motive of the defendant, the amount of harm caused to the goods, and the expense and inconvenience suffered by the owner (Brazier \& Murphy 1999: p. 54). In the discussions below x-raying the common law jurisprudence of the tort of conversion, we identify the various forms of conversion.

\subsubsection{Conversion by Taking}

It is conversion to take goods without lawful justification out of the possession of the person entitled to them with the intention of exercising a permanent to temporary dominion over them (Fouldes v. Willoughby, 1841:1153). For Example, a thief who steals another's property commits conversion, so does a person purporting to exercise a lien he does not have; not to mention a seller of goods who, having dispatched them, wrongfully re-takes them from the carrier (even temporary), or an acquaintance who, without permission, drives the plaintiff's car away and returns it the next day (Aitken v. Richardson, 1967:65). In Davies v. Lagos City Council, (1973:151) the City Council wrongfully seized the plaintiff's taxicab when he breached a term in the hackney agreement. The act was held to constitute trespass as well as conversion.

\subsubsection{Conversion by Destruction, Misuse or Alteration}

A conversion by destruction takes place not merely when a chattel is burnt or broken to pieces but when it is so dealt with in such a way that its identity is destroyed, provided the destruction is willful. Therefore, to drink wine, to spin cotton into yarn, to grind corn into flour, or to apply any process of manufacture to raw material, may undoubtedly be an act of conversion if done without the authority of the persons entitled (Dias, 1989: p. 1239).

\subsubsection{Conversion by Using}

If the defendant uses the plaintiff's chattel as if it were his own, his act is inconsistent with the rights of the plaintiff and he will be liable in conversion. Thus, it 
is conversion if the defendant merely wears the plaintiff's jewelry, or uses the plaintiff's wine bottles to store his wine. In addition, where the defendant is lawfully in possession of the plaintiff s goods such as a bailee, he will be liable in conversion if he uses it contrary to an express term in the contract of bailment prohibiting use by the bailee (Kodilinye, 1982: p. 198).

\subsubsection{Conversion by Receiving}

To receive goods voluntarily from a person who does not have title to them, in pursuant to a commercial transaction is conversion actionable by the owner (Brazier \& Murphy, 1999: p.56). Thus, where a person without lawful authority, transfers another's chattel to a third party, the mere voluntary reception of the chattel by the third party constitutes conversion in favour of the owner, even though the transferee may have acted innocently (Kodilinye, 1982). For instance, it is conversion where a purchaser received goods from an untitled seller, and where a banker received a cheque from a person who had no title to it and credited the proceeds into his account. However, a purchaser who receives goods from an untitled seller may not be liable in conversion where the goods are sold in an open market in accordance with the usages of the market (Section 31, Sale of Goods Law, Western Nigeria), and where the true owner is precluded by his conduct from denying the seller's authority to sell (Pearson v. Rose \& Young Ltd. 1951:275).

\subsubsection{Conversion by Wrongful but Effective Sale}

In the above circumstances where the seller has no title, yet property in the goods validly passes to the buyer, so that he (the buyer is not liable in conversion, i.e. market overt, or mercantile agent), the seller is still liable for conversion of goods, since the buyer received good title, even against the true owners. Thus, a person who without lawful authority disposes or transfers goods, whether by way of pledge, mortgage, or mere delivery simpliciter, with the intention of transferring the title or some other right in the goods, coupled with actual transfer of possession, commits the tort of conversion (Brazier \& Murphy, 1999: p. 57). In Chukwurah v. C.F.A.O. Motors Ltd (1967:168) for instance, the plaintiff took his car to the defendant's garage for repairs. After the work had been completed, the plaintiff refused to pay the bill presented to him or to remove the car from the defendant's premises. Nine months later, the plaintiff still having failed to settle the bill or remove the car, the defendants had the vehicle re-registered in the name of a third party who used the car as his own. The defendants were held liable in conversion, even though they had a legitimate lien on the car and could refuse to deliver it to the plaintiff until their bill was honoured.

\subsubsection{Conversion by Mis-Delivery of Carrier or Warehouseman}

A carrier or warehouseman, who by mistake delivers goods to the wrong person, commits the tort of conversion whether or not his mistake was innocent. It is immaterial if he delivers the goods to the owner if the true owner has no right to receive the goods. For instance, a holder of a lien can sue a carrier for conversion 
who in breach of the contract of carriage delivers the goods to the true owner (Sze Hai Tong Bank v. Rambler Cycle Co. 1959:576); also, a carrier may be liable in conversion if he delivers to the consignee after receiving a valid notice to stop in transit.

\subsubsection{Conversion by Detention}

Where the defendant is in possession of the plaintiff's chattel without lawful authority and refuses to surrender it to the plaintiff on demand, he is liable for conversion. Most of the circumstances that fall under this mode of conversion are situations where the possession of the defendant was originally or initially lawful but became unlawful by the failure to surrender on demand without justifiable cause. However, it also covers situations where the defendant obtained the goods by unlawful means (this type of conversion can also sustain an action in detinue, and the plaintiff may elect to sue under either torts). The ordinary way of showing conversion by unlawful retention of property is proof that the defendant refused to give it up on demand by the party entitled to it (Dias, 1989: p. 1234). Thus, for instance, where a bailee retains possession of goods after the bailment has come to an end, he does not commit conversion by the mere act of "holding over", he will be liable only if the bailor has made a demand for the return of the goods and the bailee has refused to comply with the demand (Trade Bank Plc v. Benilux Ltd. 2003:427).

\subsection{Subject Matter of Conversion}

What is the meaning of "goods" or "chattel" for the purpose of conversion? A person can only be held liable for the tort of conversion if he deals with the "goods" of another in the manner described above. However, the definition of goods for this purpose is quite uncertain. Under the English Tort (Interference with Goods) Act 1977, goods include "all chattel personal other than things in action and money". This Act is not binding in Nigeria; therefore, we cannot take the benefit of the definition. Thus, Nigerian law on this subject remains the position under the common law. Notwithstanding, the definition of goods under the common law corresponds with the English Act. Under the common law, an action would lie only for the taking or conversion of a corporeal, personal property including papers and title deeds other than money, regarded as currency (Dias, 1989: p. 1242). Thus, if a man receives a sum of money from another to be repaid later on request, his only liability is for the debt and not for conversion of the money if he refuses to pay. The only circumstance where money can be the subject matter of a conversion is where it is considered not for its value but its specific metal or paper quality. Therefore, if the undertaking was that the person would hand back or return the specific coin or note entrusted to him and he converted them to his own use, an action could lay in conversion. These principles were explicitly stated in the Nigerian case of Afribank PIc v. Ishola Investment Ltd. (2003:1841). In this case, the respondent as plaintiff in the lower court maintained a fixed deposit account with the appellant as defendant and it 
was agreed that the appellant would pay a certain percent interest per annum on the deposit for the agreed period. However, before the duration would expire, the respondent repudiated the fixed deposit agreement and gave notice of his intention to withdraw the whole deposit, but the appellant refused to give him access to the money on the ground that it had received instructions from the Central Bank of Nigeria to freeze the respondent's accounts. Dissatisfied, the respondent as plaintiff sued, claiming among other things damage for wrongful detention of money. The lower court entered judgment in favour of the plaintiff/respondent and awarded damages in his favour, the defendant them appealed to the Court of Appeal. The court allowed the appeal and noted that the cause of action in detinue and conversion could not stand because the money in the account cannot be interpreted as goods for the purpose of an action in conversion.

Note however, that money has been held not to constitute "goods" for the purpose of conversion. Notwithstanding, in certain circumstances, negotiable instruments in general, and other securities such as guarantees, insurance policies and bonds, can be the subject of actions in conversion. The rationale is that the law considers the withholding of negotiable instrument as the actual misappropriation of the piece of paper (i.e. cheque leaf), which is a conversion of chattel. This satisfies the demands of commercial convenience by allowing the full value represented on the negotiable instrument to be recovered in actions for conversion (Brazier \& Murphy, 1999: p. 52). A recent Nigerian case that recognizes this principle is Trade Bank Plc v. Benilux (2003:416), the respondent had a cheque issued in its favour for the sum of one million Naira by another company. The cheque was marked "A/C payee only" and "Not Negotiable". It was drawn on the account of the company at one of the branches of the appellant in Lagos. The cheque mandated the appellant to pay the respondent the money, but instead the appellant paid the amount represented on the cheque to a different person. The respondent sued for conversion and for the value of the cheque with interests. The High Court and Court of Appeal gave judgment in favour of the respondent, and the appellant appealed to the Supreme Court, which also dismissed the appeal. The Court held that the appellant was guilty of the tort of conversion by paying the proceeds of the cheque to another person (Ibid: 433).

An action can also be sustained in conversion for realties (things attached to land) if such realties are severed and taken away. Thus, a remedy may be obtained in conversion for coal wrongfully worked, timber wrongfully cut or fixtures wrongfully removed (Belgrave Nominei v. Berlin-Scott Air Conditioning, 1984:947).

\section{The Jurisprudence of the Tort of Detinue}

The gist of liability in detinue is the detention, wrongfully of the plaintiff's chattel. The action for detinue ensues when the defendant has in his possession the plaintiff's chattel and on demand for the return of the chattel by the plaintiff, the 
defendant withholds it. Thus, there must be demand by the plaintiff for the defendant to return the chattel and if the defendant on receipt of this notice of demand persists in keeping the chattel, he is liable in an action for detinue (Kosile v. Folarin, 1989:17).

The defendant who is in actual possession may come about the goods by lawful means (i.e. bailment) or in any other way, but his right to keep them must have extinguished and reside in the plaintiff at the time an action is brought for detinue against him, otherwise such an action is bound to fail. Thus, in First Bank of Nigeria Plc v. Olufemi Songonuga (2007:230) it was held that the appellant was not liable in detinue because it had the right of immediate possession of the title deeds of the respondent's property under a contract of guarantee, which was duly executed by the respondent, even though the respondent subsequently claimed to have terminated the guarantee (Ibid: 269). Like Conversion, an action for detinue may often involve principles relating to the law of contract, property law and principles of tortious liability.

One important thing to note when considering the law governing the tort of detinue in Nigeria is that the same facts that may sustain an action in detinue may also simultaneously create a cause of action in conversion by detention. Thus, the tort of detinue essentially covers the same grounds as the tort of conversion by detention. The only situation where facts leading to liability for detinue will not correspondently raise liability for the tort of conversion is where a bailee is unable to return goods to the owner on termination of the bailment as a result of loss or destruction due to his negligent (Rogers, 1998: p. 596). In this case, liability for non-delivery of the goods would not lay in the tort of conversion but not in detinue. Apart from this situation, there are only few other differences between the chattel torts of detinue and conversion by detention. Thus, whereas refusal to surrender on demand is the essential ingredient of the tort of detinue (i.e. the plaintiff need not prove that the defendant dealt with the goods in a manner inconsistent with his right to immediate possession of the goods), such refusal is only one of several forms of conversion (Fleming, 1983: p. 53). Another difference between the two chattel torts relates to the right of the plaintiff to sue. In conversion, only the owner of goods or the person with the immediate right of possession can sue. While this seems to be the position in an action for detinue at common law, the Nigerian Supreme Court in the case of Sodimu v. Nigerian Ports Authority (1975:15), appears to have rejected it. Thus, in Nigeria, it is not enough merely to prove that the plaintiff has an immediate right to possess the chattel; it must also be proven that he is the owner of the goods or chattel, the subject matter of dispute. In effect, it is more difficult to establish right to sue in detinue under Nigerian law than it is in conversion. It was for this reason that the learned trial judge dismissed the plaintiffs action for detinue in Commissioner of Police v. Oguntayo (1993:264), yet the Court of Appeal sustained the claim for conversion on the same facts because it merely required a right to immediate possession (Fekumo, 2000: p. 121). 
Indeed, this position works hardship on plaintiffs and leads to unfairness in the dispensation of justice in Nigeria. This is confirmed in the case of M. F. Kent (W. A.) Ltd v. Martchem Ind. Ltd (2000:459) where the respondent as plaintiff at the High Court sued the appellant seeking delivery of a Doutz 50 KVA generator and the sum of $\mathrm{N} 8000$ per day, as rent. He claimed that he bought the generating set and other items from the appellant, who delivered all the other items except the generator even after several demands. This was denied by the appellant. Judgment was given in favour of the respondent at the High Court. On appeal, the Court of Appeal allowed the appeal holding that because the respondent failed to prove ownership of the generating set in addition to the fact that it has immediate right of possession, it cannot succeed in detinue. Consequently, in Lufthansa Airlines v. Odiese (2006:34), the Court Appeal held that for a plaintiff to succeed in a claim of detinue he must adduce credible and sufficient evidence to establish the following facts: 1) that he is the owner of the chattel or property in question; 2) that he has an immediate right to possess it; 3) that the defendant is in actual possession to deliver up the property; 4) that he has made proper demand on the defendant to deliver up the property to him; and 5) that the defendant, without lawful excuse has refused or failed to deliver up the property to him.

While this distinction remains the only distinguishing feature between the torts of detinue and conversion by detention in Nigeria, operationalizing the distinction in practice works hardship on litigants, and because the practice is unknown at common law, there are increasing voices against its continued retention in Nigerian law. Perhaps, there is need to revisit this position to allow persons with possessory or proprietary interest in chattel/goods sue in detinue in Nigeria (Fekumo, 2000: p. 122). Notwithstanding this need for reform, Nigerian courts in practice usually substitute one tort for the other in circumstances in which both torts are applicable to the facts, especially in circumstances where the tort of detinue will fail due to insufficient proof of ownership. For instance, in Osaghae v. Ugen (1979:179), the action was brought in detinue, but since it was also consistent with conversion, the Court of Appeal held that the proper cause of action was conversion and the measure of damages was so computed, although it fell far below that which would have been awarded if the claim had succeeded under detinue. On the other hand, in Commissioner of Police v. Oguntayo (1993:259), the action was brought in conversion and in the alternative, detinue. The learned trial judge treated it as one of detinue, but dismissed it for want of proof of title of the plaintiff. On appeal to the Court of Appeal, the Court held the defendants liable in conversion and dismissed the alternative claim in detinue.

These cases demonstrate the attendant problems involved in associating a cause of action with the torts of detinue or conversion in Nigeria, especially where on the one part, sufficient proof is inordinately difficult to attain while on the other part, the quantum of damages recoverable is unsatisfactory. Thus, the more sensible thing to do is for the legislature in Nigeria to follow the develop- 
ment in other jurisdictions relating to the emergence of the tort of "wrongful interference with goods" which abolishes the tort of detinue and enlarges the tort of conversion to incorporate detinue (Fekumo, 2000: p. 137).

\section{The Jurisprudence of the Tort of Trespass to Goods}

Admittedly, the earliest tort against interference with goods was the tort of trespass de bonis asportatis, which is the forerunner of the modern tort of "trespass to goods" (Rogers, 1998: p. 583). The tort was directed against certain wrongs that targeted the plaintiff's possession of his goods, such as removing or taking the goods from the plaintiffs possession, or damaging them or causing any injury whatsoever to them. Thus, the central question at the heart of any action for trespass to goods was and still remains whether the defendant has directly interfered with the plaintiff s possession, and whether such interference was intentional, negligent or without any fault at all.

The tort essentially protects three interests: the plaintiff s interest in retention of possession of his goods; the plaintiff s interest in the physical condition of his goods; and the plaintiff's interest in the inviolability of his goods, i.e. against intermeddling of any kind (Forson v. Koens 1975:484). The protection of these interests is so fundamental that the law requires no prove of actual damage to the goods before liability for trespass is evoked. Trespass to goods therefore, like other forms of trespass is actionable per se, (i.e. without proof of actual damage). Thus, the slightest un-permitted touching or moving of a chattel, without any harm is actionable (Kodilinye, 1982: p. 191). However, liability for trespass to goods is not a case of strict liability. The plaintiff is required to prove some degree of blameworthiness on the part of the defendant. If the defendant's act is purely accidental, liability will not lie for trespass. Thus in National Coal Board v. Evans (1951:861), the defendant contractors unwillingly and without negligence damaged an underground cable which the plaintiff s predecessors had laid in the ground without notification to the landowners. The Court of Appeal held that there was no liability in trespass, and that inevitable accident amounted to a good defence. The law is that, the defendant's act of trespass must be intentional or negligent for liability to lie in trespass (Rogers, 1998: p. 586). The defendant's act of interference is intentional if he intends to achieve or bring about the effect of the interference with the plaintiff s goods. Once the intention exists, it is no defence that the defendant would not have committed the trespass if he had not mistaken his right to interfere, or that he did not realize he was committing a trespass (Kodilinye, 1982: p. 192). For example, if D uses P's toothbrush thinking that it is his own, he is liable in trespass since his act in using the toothbrush is intentional and the fact that he did not realize he was committing a trespass is immaterial (Wilson v. Lombank Ltd. 1963:1294).

The defendant may also be liable in trespass if he acts negligently in producing an injury to the plaintiffs goods. This is called negligent trespass to goods or unintended trespass. He is negligent if he does the act carelessly or recklessly 
without minding if it will cause damage or not. In this case, the defendant is still liable even if he did not foresee the legal consequence of his negligent act of interference (Dias, 1989: p. 1297).

\subsection{Forms of Trespass to Goods}

Trespass to goods is a wrongful physical interference with goods. The tort takes innumerable forms, such as destroying, damaging, or merely using goods, or wrongfully moving them from one place to another, or even bringing one's person into contact with them, or directing a missile at them (Hamps v. Darby 1948:311). All these actions constitute trespass. A good example is the Nigerian case of Davies v. Lagos City Council (1973:151). The defendant Council had granted the plaintiff a hackney carriage license to operate a taxicab in the Lagos area. The plaintiff was aware that the permit was not transferable, however, he went ahead to transfer it to a third party, who operated a taxicab on the strength of it. On learning of this, certain officials of the Council, in the purported exercise of their power to revoke the permit, seized the plaintiff's taxi and detained it. In an action for trespass brought by the plaintiff, Adefarasin J. held that the Council was entitled to revoke the plaintiff's permit for non-compliance with the regulations governing the use of hackney carriage licenses, but it was not entitled to seize the vehicle or otherwise take possession of it.

The only qualification for an act to constitute trespass is that the interference must be direct. This means that the touch or intermeddling by the defendant must be directly applied upon the object or chattel in the possession of the plaintiff. If the contact with the chattel was an indirect result of the defendant's conduct, it will not suffice as trespass (Susu, 1996: p. 38).

\subsection{Right of Plaintiff to Sue in Trespass}

Unlike the position under the torts of conversion and detinue where a person who has an immediate right to possession or ownership of the goods could sue even though he is not in actual possession of the goods, in trespass, the situation is the opposite. The plaintiff in an action for trespass to goods must show that he was in actual possession of the goods at the time of the alleged meddling or interference by the defendant (Brazier \& Murphy, 1999: p. 69). Ownership of the chattel is irrelevant in considering the question of liability in trespass. What matters is possession, whether actual or constructive. Thus, a cyclist who parks his cycle outside a shop remains in constructive possession of it, and could sue any thief who rides away on it. However, since the thief acquires actual possession, although wrongfully, he could also maintain an action in trespass against any third party who interferes with the cycle, except the owner himself or a person acting under the authority of the owner.

One implication of the above principle is that, even an owner of chattel may be liable in trespass if he interferes with it at a time when it is in the lawful possession of another person such as a bailee. For instance, the owner of a car who 
leaves it at a garage for servicing or repairs may be liable in trespass, if he retakes the car before the bailment has come to an end by settlement of the bills (Kodilinye, 1982: p. 193). So also, an owner of chattel cannot maintain an action in trespass if he is not in actual possession of it at the time of the interference, unless the goods were unlawfully taken from him.

There are only few exceptions to the rule that only a person in actual or constructive possession can sue in trespass, for instance, a trustee not yet in possession may sue in trespass against any third party notwithstanding that the chattel is in the hands of the beneficiary. Also, an executor or administrator of an estate may sue in trespass against anyone who interferes with the chattel of the deceased before probate or letters of administration are granted.

\section{Judicial Confusion in the Award of Damages under the Torts of Conversion, Detinue and Trespass to Goods in Nigeria}

In Nigeria, the remedies available for the wrongful interference with goods under the three torts of conversion, detinue and trespass to goods are largely similar. In the case of trespass, where the interference is temporary, the normal remedy is an award of damages; where the plaintiff suffers damage from the interference due to loss of use of the goods, he is entitled to recover general damages for "loss of the goods" (Brazier \& Murphy, 1999: p. 71). He may also recover special damages for loss of profits from the goods if he can prove that he suffered loss of profits due to the temporary interference. Where on the other hand, the interference leads to permanent loss of the goods, the plaintiff is entitled to their value by way of damages (Furness v. Advium Industries Pty Ltd. 1996:668). However, where he suffers no damages at all, he can only recover nominal damages for the wrongful interference with his goods.

These remedies applicable in trespass are also available mutatis mutandis to the torts of conversion and detinue. For instance, Lord Diplock in the case of General and Finance Facilities Ltd. v. Cook Cars (Romford) Limited (1963:650) summarized the remedies for conversion as follows:

1) An order for the delivery of the goods, and for payment of any consequential damages, or

2) An order for delivery of the goods, but giving the defendant the alternative of paying damages by reference to the value of the goods, together in either alternative with payment of any consequential damages, or

3) Damages (Rogers, 1998: p. 613)

On the other hand, the Nigerian Supreme Court in the case of Civil Design Construction Nig. Ltd. v. SCOA Nigeria Limited (2007:364) made a similar summation regarding remedies available for the tort of detinue, which include:

1) claim for value of the chattel as assessed and damages for its detention; or

2) claim for return of the chattel or recovery of its value as assessed and damages for its detention; or 
3) claim for return of the chattel and damages for its detention

These similarities in the nature of remedies available for the torts of trespass, conversion and detinue make the strongest case ever for the desegregation of the torts into a single tort of interference with goods in Nigeria. In fact, in Alfred Darefooh v. Halim Karam (1941:113) the West African Court of Appeal muted and encouraged this idea when it held that: "the quantum of damages in both forms of action being the same, it is immaterial whether the plaintiff sued in conversion or detinue". However, at common law there is a slight difference in the remedies available for conversion vis-à-vis detinue. This has to do with the 'time' of assessment of damages or market value of the goods converted or detained in the alternative to full restitution. At common law, where the goods converted or detained are no longer in possession of the defendant (sold, destroyed or disposed), the usual remedy for the plaintiff is judgment for the market value of the goods (Dias, 1989: p. 1275). In the case of conversion, this is calculated at the time the goods were converted, together with any consequential loss (F. H. A. v. Sommer \& Ors. 1986:544). In detinue however, the assessment of "market value" is made at the time or date of delivery of the judgement, together with a sum of money representing the normal consequential loss due to the detention (Zenon v. Idrissiyya, 2006:246; Guinness v. Nwoke, 2000:147; Fekumo, 2000: p. 123).

This difference in the assessment of market value remains the only distinguishing factor between the torts of detinue and conversion by detention at common law. Indeed, other heads of damages awarded for consequential losses remain the same in these torts including loss of earning or profits, general personal inconvenience and any such other losses that are not too remote to be recoverable in law (Rogers, 1998: p. 612; Graham v. Voigt, 1989:11). Note however that this distinguishing factor produces a legal dilemma in both the minds of prospective litigants and the court on the appropriate claim to make in view of the disproportionate value of damages that may be awarded depending on whether the claim is made in conversion or detinue. This is possible because in most cases, the plaintiff may claim under both torts simultaneously. In such cases, the court is usually at a crossroad on how to determine the quantum of damages, which may lead to conflicting consequences. This played out well in the case of Ordia v. Piedmont (Nig.) Ltd. (1995:533), where the trial court awarded damages in conversion, while the Court of Appeal and Supreme Court thought otherwise and awarded damages instead in detinue on the same facts. Consequently, the Supreme Court assessed the damages recoverable as value of the goods at the date of judgment, not the date of the defendant's refusal to return it.

The practice of Nigerian courts when presented with a case where the facts give rise to a cause of action simultaneously in detinue and conversion by detention has been to adopt the liberal approach, which awards damages to cover the actual loss suffered by the plaintiff notwithstanding the tort that produces the result (Zenon v. Idrissiyya, 2006:246). The Supreme Court applied this logic in 
two cases: Civil Design Construction Nig. Ltd. v. SCOA Nigeria Limited (2007:364) and Owners of M/V Gongola Hope \& Anor. v. Smurfit Cases Nigeria Ltd. \& Anor. (2007:214), the court elected to assess damages in detinue even though it acknowledged that the facts could give rise to a cause of action in both conversion by detention and detinue. In the Civil Design Construction Case, the appellant bought two Ingersoll Cyclone Water Well Rigs, No. LA 2632 WD and No. LA 8509 WD respectively, from the respondent on hire purchase. He eventually paid the full purchase price of the first rig No. LA 2632 WD and became the owner. The second Rig was not yet fully paid. A third transaction involved two Scrappers, which the appellant bought from the respondent and fully paid, but later return them to the respondent to sell and refund the purchase price. The appellant also deposited with the respondent his rig No. LA 2632 WD for servicing and repairs. Subsequently, the respondent refused to return the appellant's rig after series of demands claiming to have held it as security for the unpaid balance of another transaction. Meanwhile, the respondent seized rig No. LA 8509 WD from the appellant due to the appellant's inability to pay up the remaining installments on the hire purchase agreement.

The appellant sued the respondent in the High Court for detinue of the two rigs, claiming the market value of the rigs. The respondent counter-claimed for the outstanding installment of one hundred thousand naira in respect of rig No. LA 8509 WD. The trial court found in favour of the appellant but also granted the counter-claim of the respondent for one hundred thousand naira outstanding installment. Dissatisfied, the respondent appealed to the Court of Appeal and the appellant cross-appealed. The court held that the appellant's claim for detinue in respect of rig No. LA 2632 WD succeeds and the sum of three million naira was awarded as the market value of the rig at the date of judgment of the lower court. As regards the illegality of the respondent's seizure of the rig No. LA 8509 WD, the Court of Appeal held that the plaintiff did not show that a rig is a motor vehicle within the meaning of Section 1 of the Hire Purchase Act. Damages awarded in the trial court were affirmed in respect of the Scrappers, while the defendant was awarded the sum of one hundred and eight thousand naira being the unpaid balance of the purchase price due on the rig No. LA 8509 $\mathrm{WD}$ and cost of repairs on the plaintiff's rig.

The appellant appealed the decision of the Court of Appeal to the Supreme Court. The court held that rigs constitute motor vehicle within the meaning of the Hire Purchase Act and therefore cannot be seized without a court order under a hire purchase agreement where more than $3 / 5^{\text {th }}$ of the purchase price has been paid. On the correct assessment and award of damages in respect of wrongful detention of appellant's rig No. LA 2632 WD and Scrappers, the court affirmed the decision of the Court of Appeal. It held that the appellant could recover under the tort of detinue in respect of rig No. LA 2632 WD. As regards the Scrappers, the court held that the correct cause of action was not in detinue but conversion and the assessment and measure of damages is the market value of 
the goods at the date of conversion together with any consequential damage flowing from the conversion.

This case clearly illustrates the difficulty and dilemma the court faces in determining the appropriate cause of action when the facts give rise simultaneously to claims in both detinue and conversion by detention. In the above case, the court was guided by the need to do substantive justice when it assessed and awarded damages in conversion instead of detinue in respect of the appellant's scrappers unlike the rigs where liability was assessed in detinue. There was already evidence before the court of an agreement for the respondent to sell the Scrappers and refund the purchase price to the appellant. The emphasis thus, was not for specific performance of the contract per se, but for the appellant to recover its purchase price, which the tort of conversion served.

In Owners of $M / V$ Gongola Hope \& Anor. v. Smurfit Cases Nigeria Ltd. \& Anor. (supra) however, the facts were different, and an action in detinue was considered as most appropriate. This case arose over the performance of a contract of carriage of goods by sea. The appellants were the carriers while the respondents/cross appellants were the owners of the goods carried. The appellants failed to deliver the 41 reels of Kraftliner Board $95 \mathrm{~m} 2050 \mathrm{~mm}$ which the $1^{\text {st }}$ appellant carried for reward by sea for and on behalf of the $1^{\text {st }}$ respondent from the seaport of Paranagna for delivery to the $1^{\text {st }}$ respondent in Lagos, Nigeria. The appellants failed to deliver the goods and gave no explanation why the goods were not delivered nor traced. Consequently, the respondents sued and claimed against the appellants specific delivery of the goods or their value and anticipated loss of profit on use of the goods if they had arrived and been processed.

At the conclusion of trial, the trial court refused the respondent's claims and struck out their case on the ground that the $1^{\text {st }}$ respondent had no locus standi while the $2^{\text {nd }}$ respondent's claim had become statute barred. The respondents appealed to the Court of Appeal, which gave judgment in their favour but failed to award interest on the awards made even though the respondents included it in their claim. Dissatisfied with the judgment, the appellants appealed to the Supreme Court while the respondents cross appealed against the judgment of the Court of Appeal for not granting all the reliefs claimed by them including the reliefs for loss of profit. The court dismissed the main appeal and allowed the cross appeal. It held that the case is most appropriately brought under the tort of detinue and that the respondents are entitled to all the reliefs sought by them for damages for loss of profit where specifically proved by evidence, and that the assessment of damages is the market value of the goods detained at the date of judgment. Ogbuagu J.S.C. after reviewing the judgment of the lower court and other relevant authorities stated as follows:

[...] a plaintiff who succeeds in his case rooted in detinue is entitled to an order of specific restitution of the chattel which is adjudged to have been unlawfully detained or in default of that, its value and also damages for its detention up to the date of judgment ... Again, this specie of damages which are special in nature must be strictly proved (Ibid: 215). 


\section{The Dilemma of Enacting a Distinct Tort of Wrongful Interference with Goods in Nigeria}

The two cases above reveal the hierarchical confusion of the courts in applying the torts of conversion and detinue in Nigeria, which engenders the need to overhaul the common law governing these torts. Perhaps, Nigeria needs to follow the example of the United Kingdom and other common law countries like Canada and Australia (Hawes, 2010: p. 225). In the United Kingdom for instance, legislation was introduced to create a statutory tort of wrongful interference with goods from the preexisting common law torts of conversion, trespass and detinue (section 1 of the Torts (Interference with Goods) Act, 1977). The new tort of wrongful interference with goods abrogated the tort of detinue (Ibid: section 2(1)) and expanded the tort of conversion to incorporate all circumstances that were actionable under detinue (Ibid: section 2(2)). It also retained the tort of trespass to goods without distorting the jurisprudence of the tort under common law (Government of South Australia, 1987: p. 26). The Act addressed most of the concerns that existed at common law regarding the concurrent application of the torts of conversion and detinue, which resulted in some of the contradictions identified in the Nigerian cases discussed above. Although, all actions that previously came under detinue at common law became actionable only under conversion, the Act expanded the reliefs that a plaintiff may seek in conversion, which were not possible under the common law. First, the Act allowed the claimant to seek relief in the specific return or delivery of goods converted, which was not available at common law for the tort of conversion (Dias, 1989: p. 1291). Second, the Act assimilated the more equitable quantum of damages available in detinue, in the event of an order to pay damages for the value of the goods, which calculates the values at the time of judgment rather than the time of the conversion (Hillesden Securities v. Rvjak, (1983:187).

Although the UK Tort (Interference with Goods) Act certainly has its shortcomings, however, it succeeded in addressing the judicial confusion arising from the discordant application of the torts of conversion by detention and detinue, which has the effect of further clarifying the law. Given the current confusion engendered in the jurisprudence of Nigerian judicial decisions, a similar enactment unifying the separate torts of conversion, detinue and trespass to goods into a distinct tort of wrongful interference with goods would certainly alleviate the hardship experienced by litigants in the aspect of award of damages. This would ensure that decisions of courts in Nigeria on wrongful interference with goods align with fairness, substantial justice and equity, and the dilemma of having to choose between two equally applicable heads of tort will be disperse.

\section{Conclusion}

In the final analysis, we have shown through case law how the common law torts of conversion, detinue and trespass to goods apply in the jurisprudence of Nigerian judicial decisions. The cases clearly reveal the confusion of the courts on 
how to determine the quantum of damages where the claims simultaneously straddle the three torts. This confusion makes a strong case for the desegregation of the torts of conversion, detinue and trespass to goods into a distinct tort of wrongful interference with goods in Nigeria similar to other jurisdictions. An enactment to create the new distinct would clarify the law applicable in situations of unlawful interference with goods in Nigeria and mitigate the hardship experienced by litigants who are made to suffer as a result of the conflicting decisions of the courts and the uncertainty it has created in this area of the law.

\section{Conflicts of Interest}

The authors declare no conflicts of interest regarding the publication of this paper.

\section{References}

Brazier, M., \& Murphy, J. (1999). Street on Torts (10th ed.). London: Butherworths.

Dias, R.W. M. (1989). Dias on Torts (16th ed.). London: Sweet \& Maxwell.

Fekumo, J. F. (2000). Measure of Damages for Conversion and Detinue in Nigeria-A Critical Review. In I. A. Ayua (Ed.), Nigerian Current Legal Problems (Vols. 4 \& 5). Lagos: Nigerian Institute of Advanced Legal Studies.

Fleming, J. G. (1983). The Law of Torts (6th ed.). Sydney: The Law Book Co.

Government of South Australia (1987). Ninety-Fifth Report of the Law Reform Committee of South Australia Relating to the Law of Detinue, Conversion and Trespass to Goods.

https://law.adelaide.edu.au/system/files/2019-02/95-Detinue-Conversion-and-Trespass -to-Goods.pdf

Hawes, C. (2010). Tortious Interference with Goods in New Zealand: The Law of Conversion, Detinue and Trespass. PhD Thesis, Christchurch: University of Canterbury.

Kodilinye, G. (1982). Nigerian Law of Torts. London: Sweet \& Maxwell.

Palmer, N. E. (1978). The Application of the Torts (Interference with Goods) Act 1977 to Actions in Bailment. The Modern Law Review, 41, 629-637. https://doi.org/10.1111/j.1468-2230.1978.tb01492.x

Rogers, W. V. H. (1998). Winfield \& Jolowicz on Tort (15th ed.). London: Sweet \& Maxwell.

Samuel, G. (1982). Wrongful Interference with Goods. The International and Comparative Law Quarterly, 31, 357-385. https://doi.org/10.1093/iclqaj/31.2.357

Susu, B. A. (1996). Law of Torts. Lagos: CJS Press Nigeria Ltd. 


\section{Judicial Authorities/Cases}

Afribank Plc v. Ishola Investment Ltd. [2003] FWLR (Pt. 141) 1841.

Aitken v. Richardson [1967] N. Z. L. R. 65.

Alfred Darefooh v. Halim Karam (1941) 7 W.A.C.A. 113.

Amblestone v. London and Kano Trading Co. Ltd. [1923] 4 N. L. R, 130.

Belgrave Nominei P/L v. Berlin-Scott Air Conditioning [1984] V. R. 947.

Chukwurah v. C. F. A. O. [1967] F. N. R, 168.

Civil Design Construction Nig. Ltd. v. SCOA Nigeria Limited [2007] 6 NWLR (Pt. 1030) 300.

Commissioner of Police v. Oguntayo [1993] 6 NWLR (Pt. 299), 259.

Davies v. Lagos City Council [1973] 10 CCHCJ 151.

F. H. A. v. Sommer \& Ors. [1986] 1 NWLR (Pt. 17) 533.

First Bank of Nigeria Plcv. Olufemi Songonuga [2007] 3 NWLR (Pt. 1021) 230.

Forson v. Koens [1975] G. L. R. 479.

Fouldes v. Willoughby [1841] 151 E. R. 1153.

Furness v. Advium Industries Pty Ltd [1996] 1 V. R. 668.

General and Finance Facilities Ltd. v. Cook Cars (Romford) Limited [1963] 1 WLR 644.

Graham v. Voigt [1989] 89 A. C. T. R. 11.

Guinness (Nig) Plcv. Nwoke [2000] 15 NWLR (Pt. 689) 135.

Hamps v. Darby [1948] 2 K. B. 311.

Hollins v. Fowler [1875] L. R, 7, H. L. 757.

Ihenacho v. Uzochukwu [1997] 2 NWLR (Pt. 487), 257.

Kosile v. Folarin [1989] 3 NWLR (Pt. 107) 1.

Lufthansa Airlines v. Odiese [2006] 7 NWLR (Pt. 978) 34.

M. F. Kent (W. A.) Ltd v. Martchem Ind. Ltd. [2000] 8 NWLR (Pt. 699) 459.

National Coal Board v. Evans [1951] 2 K.B. 861.

Ordia v. Piedmont (Nigeria) Ltd. [1995] 2 NWLR (Pt. 379), 516.

Osaghae v. Ugen [1979] 6 C. A. 197.

Owena Bank (Nig.) Ltd. v. Nigerian Sweets \& Confectionery Co. Ltd. \& Anor. [1993] 4 NWLR, (Pt. 290) 698.

Owners of $M / V$ Gongola Hope \& 1 Anor. v. Smurfit Cases Nigeria Ltd. \& Anor. [2007] 15 NWLR (Pt. 1056) 189.

Pearson v. Rose \& Young Ltd. [1951] I KB 275, C. A.

Sodimu v. Nigerian Ports Authority(1975) 4 S. C. 15.

Sze Hai Tong Bankv. Rambler Cycle Co. [1959] A. C. 576.

T. Shaik \& Co. Ltd. v. Incar (Nigeria) Ltd. [1976] 5/CCHCJ 1525.

Trade Bank Plc v. Benilux (Nig) Ltd [2003] 9 NWLR, (Pt. 825) 416.

Uzor v. Boniface Anyika \& Co. [2002] FWLR (Pt. 107) 1155.

Wilson v. Lombank Ltd. [1963] 1 WLR 1294.

Zenon Pet. \& Gas v. Idrissiyya Ltd. [2006] 8 NWLR (Pt. 982) 221. 